Berkeley Law

From the SelectedWorks of Robert Cooter

November, 2011

\title{
The Secret of Growth Is Financing Secrets: Corporate Law and Growth Economics
}

Robert D. Cooter

Hans Bernd Schaefer 


\title{
The Secret of Growth Is Financing Secrets: Corporate Law and Growth Economics
}

\author{
Robert Cooter University of California, Berkeley \\ Hans Bernd Schäfer Bucerius Law School
}

\begin{abstract}
Innovative businesses unite capital and new ideas, which requires overcoming the double trust dilemma: when investors fear losing their wealth and innovators fear losing their ideas. To overcome this dilemma, seventeenth-century spice traders invented the joint stock company with an essential feature of modern corporations: entitlements to marketable shares of future profits. Using the corporate form, innovative business ventures can often be organized so that innovators expect to earn more from their share of profits than from stealing the investors' money, and investors expect to earn more by preserving the company's secrets than by disseminating them. The corporation thus provides a protected space for holding creative secrets while developing them. By developing the innovations that transform economies, the corporation became the dominant economic form of business organization.
\end{abstract}

\section{Introduction}

How did the corporation become the dominant form of business organization? Robert Cooter took the graduate course in industrial organization at the Harvard University Economics Department in 1973, which Richard Caves taught superbly. The course was organized around the approach pioneered by Edward Mason and Joe Bain called "structure, conduct, and performance" (Bain 1968), in which the performance of an industry is regressed on its structural characteristics. By connecting market structure to performance, this approach bypassed the conduct of firms. The firm is a black box whose insides are unobserved. In contrast, Ronald Coase counseled economists to look inside the firm, focusing especially on the contracts that firms write. At the end of the course, the class switched

Prepared for the conference Markets, Firms, and Property Rights: A Celebration of the Research of Ronald Coase, at the University of Chicago Law School (December 4-5, 2009). This essay is based on chapter 9 ("Developing Secrets-Corporations") in Cooter and Schäfer (2011).

[Journal of Law and Economics, vol. 54 (November 2011)]

(C) 2011 by The University of Chicago. All rights reserved. 0022-2186/2011/5404-00XX $\$ 10.00$ 
approaches and peeked inside the firm, beginning by reading Coase's (1937) classic article on the firm. For Cooter, this was like standing on Mount Pisgah with Moses and peering into the Promised Land.

Looking inside the corporation, we can see why it became the dominant form of business organization: it provides the best way to organize the risky ventures that transform economies. To see why, consider a decisive development in firms that occurred in England and Holland in the seventeenth century. In a port such as London, a bold ship's captain would propose that investors finance a voyage to Asia to obtain spices. The investors had to provide capital for a voyage lasting several years, and the ship's captain had to share secrets about how to get to Asia, where to go when he arrived, and how to trade with the foreigners. Ignorance, weather, and piracy made the voyages highly risky. The adventurers and investors received shares entitling the owner to part of the voyage's wealth. ${ }^{1}$ When the townspeople spotted a vessel returning to the harbor after a successful voyage, the shareholders rushed to the docks to monitor the cargo. At the dock,

$q^{2} \quad$ a "general court was called," meaning that a meeting of all shareholders was organized. The general court divided the cargo and then dissolved the company (Harris 2009).

Similarly, in twentieth-century Silicon Valley, a bold innovator would propose that venture capitalists finance a new technology. The investors had to provide capital for development lasting several years, in exchange for which the innovator had to share many secrets about the technology and business plan. If the venture succeeded decisively, the innovator and investors usually ended their collaboration through the sale of the startup firm to an established company or an initial public offering of its stock. In the seventeenth-century spice trade and in twentieth-century Silicon Valley, business ventures involved up-front investment, valuable secrets, high risk, extraordinary profits, and quick exit.

Launching a risky business usually requires combining capital and secrets. The investors fear losing their wealth, and the innovators fear losing their secrets. This is the double trust dilemma of development, a new name for an underdeveloped idea that draws from a rich economics literature. ${ }^{2}$ This dilemma is solved when the innovators expect to earn more from the venture than from stealing the investors' money, and the investors expect to earn more by keeping the company's secrets than by disclosing them to others. For a spice venture,

\footnotetext{
${ }^{1}$ The joint stock company has earlier origins. In the Middle Ages, the republic of Venice monopolized trade with Alexandria, through which the products of Asia flowed. The Venetians improved a legal form from classical Roman times (fraterna compagnia). In case of a loss of a ship, every merchant lost a share instead of one merchant losing everything. Commercial risk spreading was a crucial condition for the rise of capitalism (Sinn 1996). In the seventeenth century, the English and Dutch greatly improved this form by allowing different parties to have different numbers of shares and allowing the owner of a share to sell it to others.

${ }^{2}$ For a discussion of the idea and its name, see Cooter and Schäfer (2011). For a general discussion of legal incentive involving asymmetrical information, see Kitch (1980). For papers relating information to the organization of firms, see Holmstrom and Roberts (1998) and Kogut and Zander (1993, 1996).
}

Wednesday Jun 062012 0I:3 I PM/JLE7437/20I I/54/S4/hale/smitht2///edited ms to production/ 1003/use-graphics/narrow/default/ 
the captain must expect to gain more from attempting the voyage as planned than from stealing the ship, and the investors must expect to gain more from keeping the captain's secrets than from using them elsewhere or selling them. For a Silicon Valley venture, the innovator must expect to gain more from developing the innovation as planned than from stealing the investors' money, and the investors must expect to gain more from keeping the innovator's secrets than from an alternative use of them. Given these expectations, the self-interest of the parties makes their agreement self-enforcing.

To create self-enforcing agreements for business ventures, seventeenth-century firms in the spice trade developed the modern corporation, which they called the joint stock company. Profit sharing gives the innovators an incentive to use the investors' money for the venture, and it provides the investors with an incentive to preserve the innovator's secrets. Since shares are marketable, the parties can exit from the deal as soon as it succeeds or fails decisively. In the spice trade, the joint stock company solved the double trust dilemma with only modest reliance on the state. In contrast, the joint stock company did not succeed in manufacturing until legal institutions improved in the eighteenth and nineteenth centuries. Further legal improvements in the twentieth century enabled the emergence of venture capitalists-investment bankers specializing in developing innovations.

The secret of growth is financing secrets, and the corporation provides the best organizational form for doing so. The extent of its use depends on the quality of legal institutions. By focusing on the importance of the corporation as a repository of innovative secrets, this essay extends the transaction cost theory of the firm pioneered by Coase.

\section{Organizations and Markets}

We first situate the corporation in the space of organizations. Organizations generally have a structure of offices created by contract and law, such as chairman, treasurer, or ombudsman. Although some members of organizations have offices, all members have roles to play. Standardization of the division of labor creates roles such as bookkeeper, mechanic, or purchasing agent. By supplying a structure of offices and roles, organizations coordinate the behavior of its members.

When the behavior of different people is tightly coordinated, observers speak as if the group has goals, purposes, intentions, strategies, interests, wishes, and actions. These are the mental attributes of a person. An organization can be described as a personified group of individuals. In an organization, the structure of offices and roles makes its individual members capable of corporate action. Its members coordinate their behavior to pursue common goals, as with a football team, symphony orchestra, church, army, partnership, or corporation. In the case of a corporation, the organization is personified in law: it is a legal person who can own assets, make contracts, sue, and be sued.

Wednesday Jun 062012 0I:3I PM/JLE7437/20I I/54/S4/hale/smitht2///edited ms to production/ I003/use-graphics/narrow/default/ 
As coordination and discipline tighten in a group of people, they become an organization. Conversely, as coordination and discipline loosen in a group of people, an organization dissolves into a collection of individuals, like voters in an election or competitors in a piano recital. Markets are organized, but they are not organizations. Markets have causes and effects, but they do not have goals, purposes, intentions, interests, wishes, or actions, except metaphorically. Participants in markets often have legal contracts with each other, but the market is not a legal person. A nexus of contracts often sustains an organization, but an organization is not just a nexus of contracts. ${ }^{3}$ Organizations buy their inputs and sell their outputs in markets that surround them, but organizations are not markets.

What kind of organization is a corporation? Let us converge toward an answer. Many organizations own property. A club, church, cooperative, trust, charity, or the state can buy and sell property such as land, buildings, and machinery. However, no one can buy or sell these organizations, because they are unowned. In contrast, some organizations, such as corporations and partnerships, are property-they can be bought and sold. Through buying and selling, ownership tends to pass to the people who can get the most value from an organization. In this respect, an organization is not different from any other marketable good. A market for organizations keeps them focused on making money, so owned organizations play the central role in economic life. In contrast, unowned organizations that focus on goals other than making money play the central role in government, religion, and social life. ${ }^{4}$

What distinguishes the corporation from other owned organizations? As the state's creation, a corporation has whatever legal powers the state gives it. ${ }^{5}$ Different legal traditions give different legal powers to different kinds of corporations, such as the joint stock company, the public limited liability company (Aktiengesellschaft), the private limited liability company (Gesellschaft mit begrenzter Haftung), the nonprofit corporation, the S corporation, the banking corporation, the codetermined corporation, and the cooperative corporation. When people speak of "the corporation," they usually have in mind a joint stock,

\footnotetext{
${ }^{3}$ Theorists who want to efface the difference between markets and firms say that firms are a nexus of contracts. This fact cannot define a firm, however, since most large organizations that are not firms are also a nexus of contracts (for example, a university, a symphony orchestra, or the department of highways). Also, some nonorganizations form a nexus of contracts, such as a Middle Eastern bazaar or the California bar. For information on the firm as a nexus of contracts, see Jensen and Meckling (1976) and Easterbrook and Fischel (1991).

${ }^{4} \mathrm{~A}$ discussion of this difference in the objectives of owned and unowned organizations is found in Cooter and Schäfer (2011, chap. 6 ["Keeping What You Make"]).

${ }^{5}$ Some organizations, such as a partnership, church, club, or family, have an existence apart from the state. They exist in fact, whether or not the state recognizes them in law. Other organizations come into existence through law, such as a corporation, trust, the bar, or the Department of Commerce. Without going through steps prescribed in law, a corporation seldom exists in fact. (There are some exceptions, notably, informal investment schemes that look a lot like a corporation without having a legal existence.)
}

Wednesday Jun 062012 0I:3I PM/JLE7437/20I I/54/S4/hale/smitht2///edited ms to production/ I003/use-graphics/narrow/default/ 


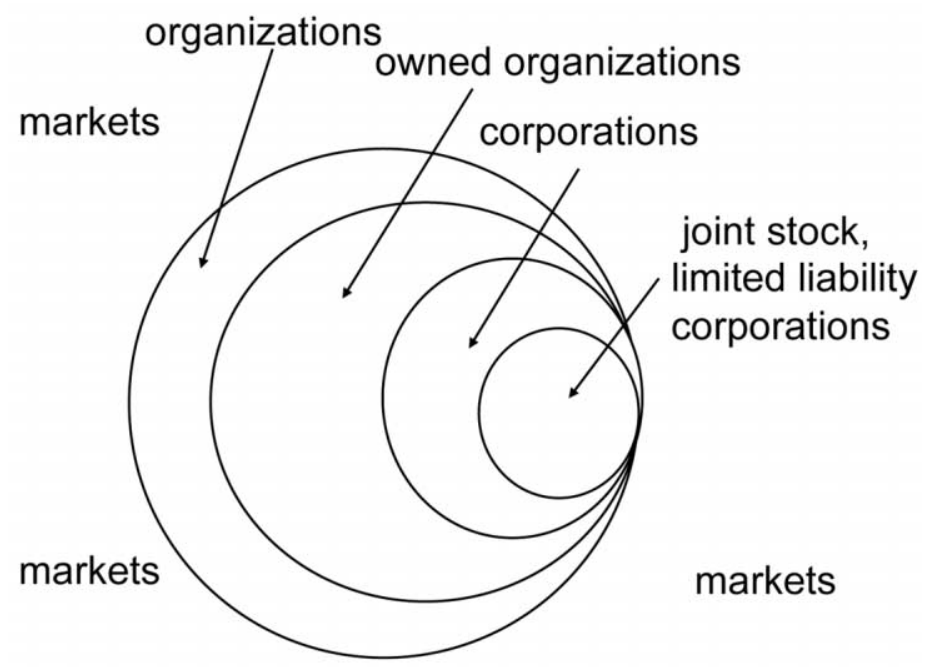

Figure 1. Perspective on corporations

limited liability corporation, which is our focus. Figure 1 presents a perspective on this type of corporation in relation to markets and organizations.

We list some traits of a joint stock, limited liability corporation. In its traditional form, investors own stock that entitles them to a share of the profits and a voice in governance. In company elections, shareholders have votes in proportion to their investments (one stock, one vote), so they control the organization jointly and unequally. In most companies, a small block of shareholders-the control block-owns enough shares with voting rights to control the company. Each investor can sell his shares to another person without obtaining the consent of other shareholders. The corporation, not its shareholders, is liable for its debts. The corporation's creditors cannot reach into the wealth of its owners. The corporation pays taxes on the profits that it earns. When it distributes profits to its investors, the investors also pay personal income taxes on these dividends.

The joint stock, limited liability corporation contrasts with a personal organization (a sole proprietorship). A personal organization is the owner's property, like his clothes and furniture, not a distinct legal person like a corporation. It cannot own property, contract, sue, or be sued. Its income is his income, and its liabilities are his liabilities. The owner has complete power to sell the organization or reorganize it. Unlike a corporation's creditors, a personal organization's creditors can reach into the owner's personal property to recover their debt, and its profits are taxed as part of the owner's personal income.

A corporation also contrasts with a partnership (or general partnership). Like

Wednesday Jun 062012 0I:3I PM/JLE7437/20I I/54/S4/hale/smitht2///edited ms to production/ I003/use-graphics/narrow/default/ 
Table 1

Characteristics of Three Types of Firms

\begin{tabular}{llll}
\hline & \multicolumn{1}{c}{ Corporation } & \multicolumn{1}{c}{ Personal } & \multicolumn{1}{c}{ Partnership } \\
\hline Legal person & Yes & No & Yes \\
Power & Controlling shareholders & Individual owner & \multicolumn{1}{c}{ Partners negotiate } \\
Liability & Limited & Unlimited & Unlimited \\
Tax basis & Corporation and stockholders & Individual owner & Partners \\
\hline
\end{tabular}

a corporation, a legal partnership is a person in law, distinct from the partners in it. It can own property, contract, sue, or be sued. Power among partners is negotiated when they form a legal organization by drafting a partnership agreement, which specifies its governance. In the simplest form of governance, the partners vote equally on fundamental matters affecting the partnership. Unlike a corporation, partners traditionally have unlimited liability for the partnership's debts, although this law is evolving. The partners usually want control over who can join them. Consequently, the partnership agreement usually restricts the ability of a partner to sell his membership to another person, which makes exit from a partnership more difficult than exit from a corporation. Unlike a corporation, the partnership traditionally does not pay taxes directly. Instead, its profits are attributed to the partners, who pay personal taxes on their income from the partnership.

Table 1 summarizes these broad generalizations about the traits of three fundamental types of firms: a (joint stock, limited liability) corporation, a personal organization (sole proprietorship), and a partnership. Different types of organizations have a place in modern economies, but corporations dominate. The corporation came to dominate the economy by becoming the lowest cost form of organization to finance the development of secrets. Economies transform through business ventures that develop innovative ideas, which requires solving the double trust dilemma. Given background legal institutions, the corporation solves the double trust dilemma best. The joint stock corporation gives innovators and investors a marketable share of future profits. This aligns the interests of innovators and investors so that innovators do not steal the firm's money and investors do not betray its secrets. In contrast, a personal organization (sole proprietorship) cannot easily guarantee investors a share in future profits, and a partnership cannot give its members a share of future profits that is easily marketable.

\section{How Big?}

We have explained the distinctive advantage of corporations that has enabled them to grow faster than other firms and to dominate the modern economy. Next we ask the question, what determines a corporation's size? To appreciate the problem, contrast two examples of large and small firms. Shopper's Stop is 
a department store in Mumbai that sells much the same goods as the Connaught Place market in New Delhi, albeit in a very different way. Shopper's Stop is one massive store with hundreds of employees selling goods in different departments. In contrast, hundreds of small, independent shops rent space in an underground structure at Connaught Place. Why does Shopper's Stop not dismiss its employees, divest its departments, and rent space to many small sellers, as Connaught Place does? Conversely, why do the small firms in Connaught Place not merge to form one large firm like Shopper's Stop?

In general, two firms can merge to make one, or one firm can divest to make two. This is the merge-or-divest question. Similarly, consider a choice faced by Kia Motors, a Korean car manufacturer. It needs tires for the cars that it makes. If it makes tires in a subsidiary, then Kia becomes that much bigger. If it buys tires from another firm, then Kia remains that much smaller. This is the makeor-buy decision. These two decisions (merge or divest, and make or buy) are examples of choices by which firms grow or shrink. To understand what determines the size of a particular firm, we need to know how they make such decisions.

Competition drives a firm toward its most profitable size. If a smaller firm is more profitable, then the firm will divest and buy inputs. If a larger firm is more profitable, then the firm will merge and make inputs. In "The Nature of the Firm" (1937), Coase argued that the more profitable choice depends on transaction costs. Manufacturing tires requires Kia to contract with employees and supervise them. These are transaction costs of making a product. Buying tires requires Kia to contract with sellers and monitor the quality of the tires. These are transaction costs of buying a product. Similarly, merging two companies requires supervising both of them, and divesting a line of production ends the firm's supervision of it. Competitive pressure should cause firms to choose the cheaper alternative between buying and making inputs or merging firms and divesting activities.

Coase's theory implies that competition should cause firms to adjust their size (large or small) and form (sole proprietorships, partnerships, or corporations) to minimize transaction costs. Entrepreneurs should be free to select a form of organization for the firm from a menu of legal alternatives. We call this proposition the principle of organizational liberty. With organizational liberty, innovative firms will choose the form of organization that minimizes the transaction cost of solving the double trust dilemma. With effective legal institutions in the background, innovative firms usually choose the corporate form.

\footnotetext{
${ }^{6}$ Connaught Place is publicly owned, so mergers and acquisitions by its lessees would have political implications.

${ }^{7}$ Other types of transaction costs analyzed by economists include agency problems, risk spreading, hold up, flexibility, and tax avoidance. The agency problem refers to the problem of managers controlling employees when contracts are incomplete (Blair and Stout 1999). Risk spreading refers to such things as avoiding liability in tort (Brooks 2002). Hold up involves specific capital investment (Williamson 1994).
}

Wednesday Jun 06 20I2 0I:3I PM/JLE7437/20I I/54/S4/hale/smitht2///edited ms to production/ I003/use-graphics/narrow/default/ 
A firm combines private information and capital in an organization. The double trust dilemma focuses on two costs of transacting: diffusion of information and appropriation of capital. Following Coase, we say, "The corporation became the dominant economic form because it reduces the cost of preventing the diffusion of innovative ideas and the appropriation of investors' money in a business venture."

We will discuss each of these advantages in turn. Before doing so, however, we briefly mention nonmarket economies. Firms throughout the communist world, such as the Nowa Huta steel plant in Poland, grew vastly larger than under capitalism. Transaction cost theory suggests why this happened. In a market economy, innovation and growth determine the size of firms. In a socialist economy, politics determines the capital allocated to a firm in the state's central plan. Socialism replaces capital markets with politics. In many institutional settings, one large firm has more political influence than two small firms. When political influence increases more than proportionately with a firm's size (increasing returns to the scale of lobbying), large firms dominate small firms politically. Thus, a politicized economy under socialism helped large firms to grow larger (see Sajó 1990). ${ }^{8}$ This explanation of gigantic firms under socialism also partly explains the large size of firms that sell mostly to the central government in a mixed economy, such as military suppliers.

\section{Keeping Secrets}

By the 1980s, gigantic steel plants in socialist countries were losing vast amounts of money, and they seemed destined to die a slow death by rust. Lakshmi Mittal, who led the international operation of an Indian steel business built by his father, believed that these industrial dinosaurs could flourish in the age of nimble business mammals. In the late 1980s, he used family money to buy ailing steel companies in Indonesia, Mexico, and Kazakhstan. More acquisitions followed, including Nowa Huta in 2003. He had novel ideas about making them profitable by shrinking and reorganizing them, and he thought that the Asian construction boom would lift world steel prices. He proved right on both counts. In 2005, Forbes rated him as the third richest person in the world.

What do entrepreneurs such as Mittal know that others do not? First, they know how to organize a business. Reorganizing gigantic steel mills to make them smaller and more profitable requires massive changes in offices, roles, and the people who fill them. Second, entrepreneurs such as Mittal know better than others what prices the future will bring, so they know which lines of business to expand and which to contract. Knowledge of organization and future prices convey a decisive advantage over competitors.

Since Mittal knew things about organization and future prices that his com-

\footnotetext{
${ }^{8}$ In general, large firms can overcome the free-rider problem of political lobbying, as explained by Olson (1965) in his classic book.
}

Wednesday Jun 06 2012 0I:3I PM/JLE7437/20I I/54/S4/hale/smitht2///edited ms to production/ 1003/use-graphics/narrow/default/ 
petitors did not, economists say that he had private information. The life cycle of innovation begins with the discovery of private information. Developing new ideas requires combining them with capital. After developing an innovation and bringing it to market, the innovation conveys a competitive advantage and yields extraordinary profits. When the venture succeeds, however, competitors sense a chance to make money and try to imitate the innovator. By withholding information from imitators, the venture firm prolongs extraordinary profits as long as possible. The longer an innovative firm can delay competitors from understanding or improving on what it knows, the more it profits and the larger it grows. Once the firm's private information stops being innovative, however, it loses its competitive advantage and stops growing.

At the start of a business venture, the innovator and investor need to combine new ideas with capital, which requires solving the double trust dilemma. Given effective law, the corporation is usually the best organization to solve it. The corporation can provide incentives for its members to retain the secrets that make a business venture succeed. The parties can structure the corporation so that investors make more money by keeping the firm's secrets than by sharing them with others and entrepreneurs make more by developing the business than by appropriating the investors' money.

In general, a successful firm is more valuable than its assets, ${ }^{9}$ so a person who steals the assets of a successful firm gains less than the firm's value. This fact enables innovators and investors to align their interests and to solve the double trust dilemma. Modern business ventures sustain alignment by complicated contracts and corporate organization. Contractual devices involve preferred stock, options to buy, options to sell, and other financial instruments. Organizational devices involve voting rights, board seats, officers, and membership on the compensation committee.

A firm should conserve the value of its private information, which often requires keeping secrets, especially when intellectual property law provides no effective protection against imitators. The firm protects its secrets partly by using such legal devices as nondisclosure agreements, noncompetition clauses, and trade secrets laws. These devices have a little value in countries with strong state law, and no value elsewhere. Thus, when technology firms negotiate in Silicon Valley, they usually sign nondisclosure agreements, which might be enforceable. In contrast, when technology firms negotiate in India, they seldom sign nondisclosure agreements, which are certainly unenforceable. ${ }^{10}$ Much the same con-

\footnotetext{
${ }^{9}$ The firm's market value is measured by how much a buyer will pay for it, including its name, reputation, goodwill, contracts, roles, and relationships. In contrast, the market value of its assets equals the sum of its parts (such as machines, buildings, materials, and accounts receivable) when sold piecemeal.

${ }^{10}$ Mitu Gulati (\#\#title, [method of communication] with ??, date\#\#) provided this information on the basis of his research into contract practices in India. However, international technology firms operating in India apparently use nondisclosure agreements.
}

Wednesday Jun 062012 0I:3I PM/JLE7437/20I I/54/S4/hale/smitht2///edited ms to production/ I003/use-graphics/narrow/default/ 
trast between Silicon Valley and India applies to suing employees or trading partners who disclose trade secrets.

The main way to protect business secrets is through organization. We propose this general principle: secrets are easier to preserve when interactions that require sharing them occur inside a firm rather than outside of it. ${ }^{11}$ Consequently, a firm should internalize production that utilizes its secrets. With respect to the merge-or-divest decision, firms that need to share secrets to cooperate can keep them better by merging. With respect to the make-or-buy decision, the inputs that a firm uses sometimes reveal secrets about its production process. A firm can better keep secrets about its production process by making some inputs rather than by buying them.

The same logic extends to many other decisions. Consider whether to hire an employee or buy a service. If performing a task requires understanding a firm's secrets, the firm should hire an employee to perform the task. Conversely, if performing the task does not require understanding a firm's secrets, the firm can buy the service from an outside contractor. Consider whether to sell a service or the product that produces it. A firm invents a computer program to perform an accounting task. If a firm owns an effective patent, it can sell the program to others to use. Conversely, if it does not own an effective patent, it should sell the accounting service to others and keep the program secret.

Consider whether to buy a product or buy the firm that makes it. Special know-how is embedded in a firm's routines, organization, and culture. The firm's embedded knowledge is sometimes called its core competence. If one firm wants the information embedded in another firm, it should buy the other firm. Conversely, if a firm does not want information embedded in another firm, it can buy the other firm's products, services, or assets such as patents. Table 2 summarizes these decisions and the criteria for making them.

\section{Financing Inside and Out}

Having discussed how firms protect secrets, we next discuss how firms protect an investor's money. Broad finance requires a firm to attract investors from outside the inner circle of people who control it. The outsiders must trust the

\footnotetext{
${ }^{11}$ We explain the boundaries of the firm by the need to protect market power by keeping innovations secret. In contrast, a celebrated analysis in Hart (1995, p. 8) explains the boundaries of the firm as conserving decision-making power. He writes, "Firm boundaries are chosen to allocate power optimally among the various parties to a transaction. I argue that power is a scarce resource that should never be wasted. One implication of the theory is that a merger between firms with highly complementary assets is value-enhancing, and a merger between firms with independent assets is value-reducing. The reason is as follows. If two highly complementary firms have different owners, then neither owner has real power since neither can do anything without the other. It is then better to give all the power to one of the owners through a merger. On the other hand, if two firms with independent assets merge, then the acquiring firm's owner gains little useful power, since the acquired firm's assets do not enhance his activities, but the acquired firm's owner loses useful power, since she no longer has authority over the assets she works with. In this case, it is better to divide the power between the owners by keeping the firms separate."
}

Wednesday Jun 062012 0I:3 I PM/JLE7437/20I I/54/S4/hale/smitht2///edited ms to production/ I003/use-graphics/narrow/default/ 
Table 2

Organizational Decisions and Informational Criteria

\begin{tabular}{ll}
\hline Decision & \multicolumn{1}{c}{ Criterion } \\
\hline Merge or divest? & Does cooperation require sharing secrets? \\
Make or buy an input? & Does the input reveal the firm's production process? \\
Hire an employee or buy a service? & Does the worker need to know the firm's secrets? \\
Sell a product or sell a service? & Can a product's user appropriate its secrets? \\
Buy a firm or its product? & Does the buyer want the target's embedded information? \\
\hline
\end{tabular}

insiders. Special features of the seventeenth-century voyages from Europe to Asia made stockholders relatively easy to protect. As a matter of practical necessity, the ship usually needed to return with its cargo to the port of embarkation where its crew lived. At the port of embarkation, the investors could see the firm's wealth and divide it. Compared to other industries, the spice trade was especially favorable to the corporate form because the double trust dilemma could be solved even though modern legal institutions were underdeveloped.

Unlike a spice voyage, a factory yields a stream of production over time, so insiders can disguise profits and divert them relatively easily. Business ventures are so risky that investors need a share of profits as compensation, not repayment $\mathrm{q}^{7} \quad$ of a fixed debt, as with a bank loan or a bond. The corporate form spread into manufacturing in Britain and the United States in the eighteenth and nineteenth centuries when many small improvements in law and institutions gave the firm's insiders the legal power to guarantee outside investors their share of profits. These improvements-including better accounting techniques, limited liability, reporting requirements, and banking regulations_-mostly have a single purpose: to separate the company's assets and liabilities from those belonging to other legal persons. Separation prevents insiders from converting the firm's assets into their personal wealth, and separation prevents the firm's creditors from converting its debts into the personal debts of the firm's investors (Hansmann and Kraakman 2001).

Improvements in partitioning assets enabled the corporation to spread in the nineteenth century. The corporations that first attracted outside investors especially concentrated on infrastructure and utilities_roads, canals, railroads, water, and so forth. These firms reassured outside investors by securing state participation and supervision. Gradually, the stock market in England and the United States spread from infrastructure and utilities into manufacturing. Legal and nonlegal improvements in partitioning assets probably contributed as much to the industrial revolution as did the factors usually cited, such as scientific progress, capital accumulation, and labor mobilization (López-de-Silanes 2007).

Summarizing a decade of econometric research on economic development, López-de-Silanes concludes, "Investor protection explains the development of q8 financial markets" (López-de-Silanes 2007, p. \#\#). Weak investor protection has a demonstrable effect on stock prices. A stock yields a stream of future dividends

Wednesday Jun 062012 0I:3I PM/JLE7437/20I I/54/S4/hale/smitht2///edited ms to production/ 1003/use-graphics/narrow/default/ 
to its owner. ${ }^{12}$ Without effective investor protection, insiders grab a disproportionate share of a firm's earnings, and little is left to pay dividends. A few shares in such a company have little value, but a controlling block of shares has much value. The price per share that people will pay for a controlling block of shares is larger than the price per share that they will pay for a small number of shares. The difference in price per share for the control block and individual shares is called the control premium. To illustrate, if insiders are willing to sell the controlling block for $\$ 1.50$ per share, whereas outsiders are willing to pay $\$ 1.00$ per share for individual shares, then the control premium is $\$ .50$ per share.

The control premium is large when insiders can divert profits to themselves rather than share them with outside investors. Conversely, the control premium is small when effective law gives outsiders their fair share of profits. Nenova (2003) calculates the control premium in different countries. In the Czech Republic, a controlling block of shares commands a premium of 58 percent relative to the stock market price. In the Republic of Korea, the premium is 47 percent. In France and Italy-countries with a strong legal system but weak minority shareholder protection-it is 28 percent. In Brazil and Chile, it is 23 percent. In Germany and the United Kingdom, it is 10 percent. In the Scandinavian countries, the United States, and Canada, it is less than 5 percent. Nenova then shows the statistical connection between the control premium and an index of strength of law in a country (the rule-of-law index). As predicted, the control premium falls when the rule of law strengthens. ${ }^{13}$

A tragic example of the control premium comes from Eastern Europe after the collapse of communism. Czechoslovakia privatized many state firms after 1989. To implement wide ownership, the state gave the stock in newly privatized firms to large mutual funds, and the state distributed vouchers to citizens, entitling them to obtain shares in the mutual funds at little or no cost. However, weak law could not stop insiders from grabbing profits from the privatized firms. Without effective legal protection, individual citizens correctly placed little value on the vouchers, so public prices plummeted, insiders snatched up shares at bargain prices, and widely held firms collapsed into closely held firms. The Czechoslovakian state tried and failed to achieve broad ownership of privatized firms. Voucher privatization, which Western economists recommended, also failed miserably in Russia during the transition from communism to capitalism after 1991 (Magin 2003).

Better investor protection should cause an increase in the stock market value

\footnotetext{
${ }^{12}$ The exception is a growth firm whose owners expect it to be acquired before it ever pays dividends. Here the price of stocks is determined by the expected future sale price of the firm, not by the present value of the stream of future dividends.

${ }^{13}$ Other empirical evidence also supports the conclusion that the control premium falls when outside investors enjoy better legal protection. Thus, Nenova obtains the same negative correlation using a more specific index of minority protection of shareholders, instead of the rule-of-law index. See also Dyck and Zingales (2004), as discussed by Gorga (2007).
}

Wednesday Jun 06 20I2 0I:3I PM/JLE7437/20I I/54/S4/hale/smitht2///edited ms to production/ I003/use-graphics/narrow/default/ 
of firms, or their market capitalization. ${ }^{14}$ To test this proposition, economists compare the market capitalization of firms in different countries. Firms are the main source of national income in most countries. Consequently, better investor protection should cause an increase in the ratio of market capitalization to gross domestic product (GDP) for a country. Empirical research confirms this prediction. The ratio of total market capitalization to GDP is roughly twice as large in high-income countries as in low-income countries. Furthermore, the ratio of total market capitalization to GDP increases with improved investor protection, as measured by an index of shareholder rights or an index of public disclosure. ${ }^{15}$

Econometric evidence shows that improvements in corporate law can increase the value of firms. Before 1947, India was a British colony, so its rules of corporate governance were British. From India's independence in 1947 until roughly 1990, socialist policies made firms increasingly dependent on state finance. Nationalized banks crowded out private financing of large firms. In the 1990s, however, socialist policies were reversed and private investing recovered. In 1999, India adopted major reforms in the law of corporate governance, known as Clause 49 , which protect outside investors against wrongdoing by corporate insiders. Provisions include mandatory disclosure, stricter accounting, and managerial responsibility for reporting. Clause 49 reforms applied immediately to large firms and gradually to smaller firms. The difference in timing permitted Black and Khanna (2007) to estimate the effect of these laws on stock values. Regression analysis concluded that the laws caused the stock prices of affected firms to increase by $4-5$ percent. $^{16}$

Another econometric test of the effect of corporate legal reform on stock prices comes from Korea. In 1999, Korea enacted new laws on corporate governance that became effective in 2000. Under the new law, large firms were required to appoint independent directors, create an audit committee, and form a nomination committee. The result, as shown by Black and Kim (2012), was a measurable increase in the stock value of affected firms. Apparently, these legal reforms made outsiders more confident about investing in Korean firms, all of which are closely held by insiders.

\section{Cheap Freedom}

The joint stock company did not become the dominant form of economic organization in manufacturing until the modernization of legal institutions facilitated asset partitioning. In addition to creating protection for outsiders,

\footnotetext{
${ }^{14}$ Improved investor protection causes an increase in total market capitalization in two distinct ways. First, outside investors bid the stock price up. Second, some strictly private firms offer shares to the public for the first time.

${ }^{15}$ Market capitalization as a percentage of gross domestic product increases with an index of public disclosure of company news, as shown by the World Bank (2006).

${ }^{16}$ The faster growing, midsize firms benefited most. The increase in stock prices was especially due to an increase in investment by foreigners (Black and Khanna 2007).
}

Wednesday Jun 06 2012 01:3I PM/JLE7437/20I I/54/S4/hale/smitht2//ledited ms to production/ I003/use-graphics/narrow/default/ 
changes in law also had to remove monopolistic restrictions on corporate activities built up over centuries. Thus, British monarchs in the seventeenth and eighteenth centuries granted monopolies to privileged subjects in exchange for loyalty and money. A patent or license gave the holder an exclusive right to engage in a certain line of business. Local patents were given for many small businesses, such as those brewing beer, and for some very large businesses, such as the Hudson's Bay Company, whose charter from King Charles II in 1670 granted a monopoly over trading with Indian tribes in much of northern Canada.

Like eighteenth-century Britain, some contemporary countries require a separate license for pharmaceuticals, securities, cable television, exports, restaurants, real estate, hotels, haircuts, opticians, and so forth. Some of these restrictions provide justifiable protection of consumers against incompetence and fraud. However, many of these restrictions reserve some lines of business for politically privileged groups. In every country, restrictive licensing shields privileged firms from competition, and they reciprocate with bribes, contributions, and other forms of support for politicians.

In Britain, legal restrictions on business eroded sufficiently in the nineteenth century that a corporation could form relatively freely and operate in many lines of business. Like nineteenth-century Britain, most developing countries today have a general incorporation that allows the firm to enter many lines of business. This development increases liberty by allowing people to organize business ventures without special permission from the state. However, the law imposes a price for exercising economic freedom, which varies from country to country. The price includes fees for licenses and registration, bribes paid to expedite processing or relax rules, minimum capital requirements for establishing a company, business taxes, and many restrictions involving employees. The World Bank (2010) survey reported in Table 3 gives the number of days and procedures needed to establish a new business in various countries. According to Table 3, the regulatory burden on new businesses varies from one country to another, and the burden is especially heavy in developing countries. ${ }^{17}$ (The general pattern in Table 3 is convincing, but the numbers contain measurement errors, so comparisons between any two countries must be treated with caution.) Innovation would increase if business freedom were cheaper to exercise.

Improving a country's courts and other legal institutions can take years. In the meantime, a firm can reassure outside investors by bringing itself under the jurisdiction of foreign courts. Cross listing companies on more than one stock exchange makes firms comply with foreign regulations that sometimes protect

\footnotetext{
${ }^{17}$ In OECD countries, the number of procedures required to register property was 4.7 on average in 2004, whereas it was 6.6 in middle- and low-income countries (World Bank 2006). Also see Enterprise Directorate-General of the European Commission (2002), which finds that setting up a new company took 7 days in the United Kingdom and 35 days in Italy.
}

Wednesday Jun 062012 0I:3I PM/JLE7437/20I I/54/S4/hale/smitht2///edited ms to production/ 1003/use-graphics/narrow/default/ 
Financing Secrets

Table 3

Legal Barriers to Establishing a New Business

\begin{tabular}{lrr}
\hline & Days Required & Procedures \\
\hline Venezuela & 141 & 16 \\
Brazil & 120 & 16 \\
Indonesia & 60 & 9 \\
Vietnam & 50 & 11 \\
China & 37 & 14 \\
Kenya & 34 & 12 \\
Poland & 32 & 6 \\
Nigeria & 31 & 8 \\
India & 30 & 13 \\
Russian Federation & 30 & 9 \\
Argentina & 27 & 15 \\
Chile & 27 & 9 \\
Pakistan & 20 & 10 \\
Czech Republic & 15 & 8 \\
Mexico & 13 & 8 \\
Malaysia & 11 & 9 \\
Iran & 9 & 7 \\
Egypt & 7 & 6 \\
Turkey & 6 & 6 \\
United States & 6 & 6 \\
Canada & 5 & 1 \\
\hline Source. World Bank & &
\end{tabular}

Source. World Bank (2010).

shareholders better than domestic regulations do ${ }^{18}$ In effect, firms gain access to outside investors by renting a regulator (Reese and Weisbach 2000; Claessens, Klingebiel, and Schmukler 2002; Karolyi 1998). In general, empirical evidence from various countries shows that cross listing a stock increases its price. ${ }^{19}$ Beyond cross listing, a firm can sometimes bring itself under foreign law by relocating its corporate charter to another jurisdiction. Empirical evidence from the United States suggests that competition for corporate charters among states probably improved the quality of corporate law (Romano 1987; Bebchuk 1992; Bar-Gill, Barzuza, and Bebchuk 2006).

\footnotetext{
${ }^{18}$ To illustrate, the Russian gas company Gazprom resembled Exxon in its size and scope of operations, but the market value of Gazprom's stock (market capitalization) in 2001 was 10 percent of Exxon's market value. This difference in value mainly reflected the difference in the protection of minority shareholders in Russia and the United States. In 2005, Russia removed restrictions against foreign investors in Gazprom, and the company promptly applied to list its stock on the New York Stock Exchange, as well as on the London Stock Exchange. To list on the New York Stock Exchange, a company must comply with its rules and also the rules of the U.S. Securities and Exchange Commission (Didenko 2005).

${ }^{19}$ Doidge, Karoly, and Stulz (2004, p. \#\#\#) examine stock prices for 712 cross-listed firms and 4,078 that were not cross listed in 1997 and find that "cross-listed stocks were worth 16.5 percent more on average than comparable firms that were not cross-listed." This cross-listing premium was even more dramatic for firms listed on New York Stock Exchange, where it was 37 percent on average.
} 
Table 4

Control of Large Publicly Traded Corporations in Selected Countries, 1995

\begin{tabular}{lccr}
\hline & Closely Held & Widely Held & State \\
\hline Mexico & 100 & 0 & 0 \\
Hong Kong & 70 & 10 & 5 \\
Argentina & 65 & 0 & 15 \\
Singapore & 30 & 15 & 45 \\
South Korea & 20 & 55 & 15 \\
France & 20 & 60 & 15 \\
United States & 20 & 80 & 0 \\
Italy & 15 & 20 & 40 \\
Germany & 10 & 100 & 25 \\
United Kingdom & 0 & & 0 \\
\hline
\end{tabular}

Source. La Porta, López-de-Silanes, and Shleifer (1998, table II).

Note. Data are percentages.

\section{The Inverse-Tightness Rule}

When state law is ineffective, firms organize especially on the basis of family, friends, and repeat transactions. ${ }^{20}$ The Rothschilds in France, Agnellis in Italy, Onassis in Greece, and Birlas in India developed large, profitable family firms. Conversely, when state law is effective, the tightening of law makes possible the organization of some firms with loose relationships. Strangers can organize firms less on the basis of relationships and more on the basis of offices and roles. The inverse-tightness rule asserts that loose state law for business causes tight relationships in most firms and tight state law for business causes loose relationships in some firms.

Applied to ownership of firms, the inverse-tightness rule implies that loose state law for business concentrates ownership and tight state law disperses ownership. ${ }^{21}$ Empirical evidence in Table 4 confirms this prediction. The table divides large firms with publicly traded stock into three types: (1) closely held, which are controlled directly or indirectly by one person, a family, or a small group, (2) widely held, which are controlled by professional managers, or (3) state owned. We see that all Mexican companies in the sample were closely held and none were publicly held or controlled by the state. At the other extreme, all

\footnotetext{
${ }^{20}$ Elsewhere we distinguish three general ways to create trust between investors and the insiders who manage an enterprise: relationships, private contracts, and public markets. See Cooter and Schäfer (2011, chap. 3 ["The Double Trust Dilemma of Development"]).

${ }^{21}$ The most fundamental laws are the rules of property and contracts found in common law and civil codes. Next in importance comes business law. To illustrate, here are some examples of rules of corporate governance that help to protect minority investors when effectively enforced: (1) cumulative voting for the board of directors, which helps minority shareholders to elect someone who will act in their interests, (2) requiring the board to have some directors who are outsiders, (3) transparent rules for selection of directors to serve on key committees, such as the nomination committee, the remuneration committee, and the audit committee, (4) requiring approval by the board for certain fundamental transactions of the company, and (5) giving one vote per share for all shares, instead of allowing some shares to have more votes than others.
}

Wednesday Jun 06 20I2 0I:3I PM/JLE7437/20I I/54/S4/hale/smitht2///edited ms to production/ 1003/use-graphics/narrow/default/ 
large U.K. companies in the sample were publicly held. According to Table 4, the widely held corporation represents less than half of publicly traded firms in Mexico, Hong Kong, Argentina, Singapore, and Italy and more than half of publicly traded corporations in South Korea, France, the United States, Germany, and the United Kingdom. ${ }^{22}$

Protecting diffuse stockholders against insiders is so difficult that few countries succeed. Recent empirical research shows that firms with dispersed ownership play almost no role in developing countries, and even in rich countries they dominate only in the United States and the United Kingdom (La Porta, Lópezde-Silanes, and Shleifer 1999). Instead of being widely held, most corporations in the world are closely held by a few people with a controlling share of stock. Although closely held, these companies often sell some stock to outsiders, especially as law strengthens.

\section{Conclusion}

Given organizational liberty, entrepreneurs will choose the type of firm that minimizes transaction costs. Unlike sole proprietorships or partnerships, the corporation gives innovators and investors a marketable share of future profits. When innovators and investors securely own a marketable share of future profits, they can align their interests so that the innovator does not steal the investor's money and the investors do not steal the innovator's idea. Given effective laws, corporations can contain business secrets and use investors' money to develop them. By solving the double trust dilemma, the corporation finances the development of secrets at lower transaction costs than other types of firms. Different organizations have a place in modern economies, but corporations dominate by launching risky ventures that transform economies.

\section{References}

Bain, Joe. 1968. Industrial Organization. Vol. 2. New York: Wiley.

Bar-Gill, Oren, Michal Barzuza, and Lucian Bebchuk. 2006. The Market for Corporate Law. Journal of Institutional and Theoretical Economics 162:134-72.

Bebchuk, Lucian. 1992. Federalism and the Corporation: The Desirable Limits on State Competition in Corporate Law. Harvard Law Review 105:1437-1510.

Black, Bernard S., and Vikramaditya S. Khanna. 2007. Can Corporate Governance Reforms Increase Firms' Market Values? Event Study Evidence from India. Journal of Empirical Legal Studies 4:749-96.

Black, Bernard S., and Woochan Kim. 2012. The Effect of Board Structure on Firm Value: A Multiple Identification Strategy Approach Using Korean Data. Journal of Financial Economics 104:203-26.

\footnotetext{
${ }^{22}$ Other studies confirm the general pattern of figure 6.4 in Gorga (2007), which cites data indicating that 90 percent of the firms in a large sample from the Brazilian stock exchange have a single stockholder owning more than 50 percent of shares. Only a few companies are controlled by a coalition of block holders.
}

Wednesday Jun 06 2012 0I:3I PM/JLE7437/20I I/54/S4/hale/smitht2///edited ms to production/ I003/use-graphics/narrow/default/ 
Blair, Margret, and Lynn Stout. 1999. A Team Production Theory of Corporate Law. Virginia Law Review 85:247-311.

Bogart, Daniel E., and Gary Richardson. 2010. Property Rights and Parliament in Industrializing Britain. Working Paper No. w15697. National Bureau of Economic Research, Cambridge, Mass.

Brooks, Richard R. W. 2002. Liability and Organizational Choice. Journal of Law and Economics 45:91-121.

Claessens, Stijn, Daniela Klingebiel, and Sergio L. Schmukler. 2002. Explaining the Migration of Stocks from Exchanges in Emerging Economies to International Centers. Discussion Paper No. 3301. World Bank, Washington, D.C.

Coase, R. H. 1937. The Nature of the Firm. Economica, n.s., 4:386-405.

Cooter, Robert, and Hans Bernd Schäfer. 2011. Solomon's Knot: How Law Can End the Poverty of Nations. Princeton, N.J.: Princeton University Press.

Deane, Phyllis. 1965. The First Industrial Revolution. Cambridge: Cambridge University Press.

Didenko, Pavel. 2005. Compliance with the Sarbanes-Oxley Act of 2002: Challenges for Russian Corporate Governance. Discussion paper. Bond University, Faculty of Law, Robina.

Doidge, Craig, G. Andrew Karolyi, and René M. Stulz. 2004. Why Are Foreign Firms Listed in the U.S. Worth More? Journal of Financial Economics 71(2):205-38.

Dyck, Alexander, and Luigi Zingales. 2004. Private Benefits of Control. Working Paper No. 8711. National Bureau of Economic Research, Cambridge, Mass.

Easterbrook, Frank, and William Fischel. 1991. The Economic Structure of Corporate Law. Cambridge, Mass.: Harvard University Press.

Enterprise Directorate-General of the European Commission. 2002. Benchmarking the Administration of Business Startups. Otford: Centre for Strategy and Evaluation Services.

Gorga, Érica Cristina Rocha. 2007. Analysis of the Efficiency of Corporate Legal Rules. Brasilia: Interlegis.

Hansmann, Henry, and Reinier H. Kraakman. 2001. The End of History for Corporate Law. Georgetown Law Journal 89:439-68.

Harris, Ron. 2000. Industrializing English Law: Entrepreneurship and Business Organization, 1720-1844. Cambridge: Cambridge University Press.

- 2003. Law, Finance and the First Corporations. Pp. 145-72 in Global Perspectives on the Rule of Law, edited by James Heckman, Robert L. Nelson, and Lee Cabatingan. Abingdon: Routledge-Cavendish.

Hart, Oliver. 1995. Firms, Contracts, and Financial Structure. New York: Oxford University Press.

Holmstrom, Bengt, and John Roberts. 1998. The Boundaries of the Firm Revisited. Journal of Economic Perspectives 12:73-94.

Jensen, Michael C., and William H. Meckling. 1976. Theory of the Firm: Managerial Behavior, Agency Costs, and Ownership Structure. Journal of Financial Economy 3:30560.

Karolyi, G. Andrew. 1998. Why Do Companies List Shares Abroad? A Survey of the Evidence and Its Managerial Implications. Financial Markets, Institutions and Instruments 7:1-60.

Kitch, Edmund W. 1980. The Law and Economics of Rights in Valuable Information. Journal of Legal Studies 9:683-723.

Kogut, Bruce, and Udo Zander. 1993. Knowledge of the Firm and the Evolutionary Theory

Wednesday Jun 06 20I2 0I:3I PM/JLE7437/20I I/54/S4/hale/smitht2///edited ms to production/ 1003/use-graphics/narrow/default/ 
of the Multinational Corporation. Journal of International Business Studies 24(4):62545.

1996. What Do Firms Do? Coordination, Identity, and Learning. Organization Science 7(5):502-18.

La Porta, Rafael, Florencio López-de-Silanes, and Andrei Shleifer. 1999. Corporate Ownership around the World. Journal of Finance 54:471-517.

López-de-Silanes, Florencio. 2007. Legal Origins and Corporate Finance. Paper presented at the 11th annual conference of the Latin American and Caribbean Law and Economics Association, Brasilia, May 25-26.

Magin, Konstantin. 2003. Reforms with No Place to Stand. Ph.D. diss. University of California, Berkeley, Haas School of Business.

Nenova, Tatiana. 2003. The Value of Corporate Voting Rights and Control: A CrossCountry Analysis. Journal of Financial Economics 68:325-51.

Olson, Mancur. 1965. The Logic of Collective Action: Public Goods and the Theory of Groups Cambridge, Mass.: Harvard University Press.

Reese, William A., and Michael S. Weisbach. 2000. Protection of Minority Shareholder Interests, Cross-listings in the United States, and Subsequent Equity Offerings. Unpublished manuscript. Tulane University, A.B. Freeman School of Business, New Orleans.

Romano, Roberta. 1987. The State Competition Debate in Corporate Law. Cardozo Law Review 8:709-57.

Sajó, András. 1990. Diffuse Rights in Search of an Agent: A Property Rights Analysis of the Firm in the Socialist Market Economy. International Review of Law and Economics 10:41-60.

Sinn, Hans-Werner. 1996. Social Insurance, Incentives, and Risk Taking. International Tax and Public Finance 3:259-80.

Williamson, Oliver E. 1994. Hierarchies, Markets, and Power in the Economy: An Economic Perspective. Business and Public Policy Working Paper BPP-59. Center for Research in Management, Berkeley, Calif.

World Bank. 2006. World Bank Development Indicators 2005. Washington, D.C.: World Bank.

2010. Doing Business 2010: Reforming through Difficult Times. Washington, D.C.: World Bank. 


\section{QUERIES TO THE AUTHOR}

q1. Please verify that author affiliations are correct as shown.

q2. Please provide the number of the page on which "general court was called" appears in Harris (2009). Should this be Harris 2000 or 2003? If 2009, please add to reference list.

q3. Please note that JLE style does not allow italics for emphasis.

q4. For the sentence "Following Coase. ..." please (a) indicate whether this quote is from the Cooter and Schäfer (2011) publication in the reference list (p. 129); (b) if not, please provide the source and page number for the quote.

q5. For note 10, please provide Gulati's title, the method of communication, and the date.

q6. OK to change "Applied to the merge-or-divest decision" to "With respect to the merge-or-divest decision" to avoid dangling modifier?

q7. Please note that the sentences "The corporate form..." and "Many small improvements" have been combined into one.

q8. For the sentence "Summarizing. . .," please provide the number of the page on which the quotation by López-de-Silanes is found, if the reference is indeed a published reference.

q9. Nenova is mentioned twice in this paragraph as well as once in footnote 13. Please verify added information for Nenova in the reference list.

q10. In the Reese and Weisbach (2000) reference, Reese's affiliation was changed from "University of Illinois" to "Tulane University" to match the affiliation shown on SSRN Web site. Okay?

q11. The following queries are for footnote 19: (a) Please verify location of insertion of closing quotation mark. (b) Please provide the number of the page on which the quotation appears in Doidge, Karoly, and Stulz (2004). The exact quote cannot be found in the article.

q12. The following references were not cited in your text: Bogart (2010), Deane (1965), Harris (both 2000 and 2003). Please indicate where citations should be inserted. 